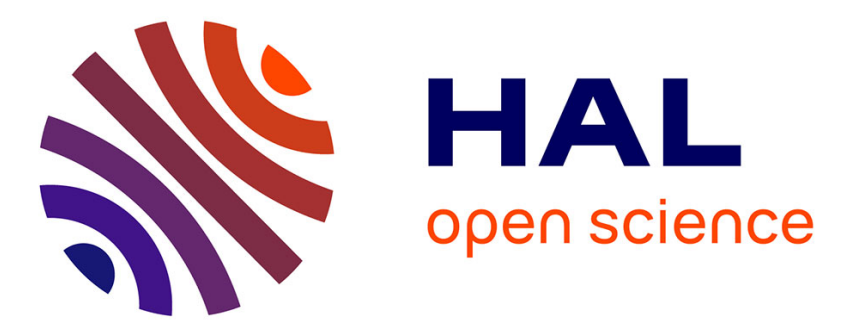

\title{
Variability of Solar Radiation and CDOM in Surface Coastal Waters of the Northwestern Mediterranean Sea
} Richard Sempere, Julien Para, Marc Tedetti, Bruno Charrière, Marc Mallet

\section{To cite this version:}

Richard Sempere, Julien Para, Marc Tedetti, Bruno Charrìre, Marc Mallet. Variability of Solar Radiation and CDOM in Surface Coastal Waters of the Northwestern Mediterranean Sea. Photochemistry and Photobiology, 2015, 91 (4), pp.851-861. 10.1111/php.12434 . hal-01799299

\section{HAL Id: hal-01799299 \\ https://hal.science/hal-01799299}

Submitted on 30 Aug 2018

HAL is a multi-disciplinary open access archive for the deposit and dissemination of scientific research documents, whether they are published or not. The documents may come from teaching and research institutions in France or abroad, or from public or private research centers.
L'archive ouverte pluridisciplinaire HAL, est destinée au dépôt et à la diffusion de documents scientifiques de niveau recherche, publiés ou non, émanant des établissements d'enseignement et de recherche français ou étrangers, des laboratoires publics ou privés. 


\title{
Variability of Solar Radiation and CDOM in Surface Coastal Waters of the Northwestern Mediterranean Sea
}

\author{
Richard Sempéré ${ }^{* 1}$, Julien Para ${ }^{1}$, Marc Tedetti ${ }^{1}$, Bruno Charrière ${ }^{1,2}$ and Marc Mallet ${ }^{3,4}$ \\ ${ }^{1}$ Aix-Marseille Université, Mediterranean Institute of Oceanography (M I O), Université de Toulon, CNRS-INSU/IRD, \\ Marseille, France \\ ${ }^{2}$ CEFREM, CNRS - Université de Perpignan, Marseille, France \\ ${ }^{3}$ Université Paul Sabatier de Toulouse, Laboratoire d'Aérologie, Toulouse, France \\ ${ }^{4}$ CNRS Laboratoire d'Aérologie, Toulouse, France
}

Received 12 September 2014, accepted 4 February 2015, DOI: 10.1111/php.12434

\begin{abstract}
Atmospheric and in-water solar radiation, including UVR-B, UVR-A and PAR, as well as chromophoric dissolved organic matter absorption $\left[a_{\mathrm{CDOM}}(\lambda)\right]$ in surface waters were monthly measured from November 2007 to December 2008 at a coastal station in the Northwestern Mediterranean Sea (Bay of Marseilles, France). Our results showed that the UVR-B/ UVR-A ratio followed the same trend in the atmosphere and at $2 \mathrm{~m}$ depth in the water $(P<0.0001)$ with an increase (eight-fold higher) during summer. The low diffuse attenuation coefficients for downward irradiance $\left[K_{d}(\lambda)\right]$ of UVR-B, UVR-A and PAR indicated that the waters were highly transparent throughout the year. The relationships between $a_{\text {CDOM }}(\lambda)$ and $K_{\mathrm{d}}(\lambda)$ in this oligotrophic system suggested that CDOM contributed to UVR attenuation in the UVA domain, but also played a significant role in PAR attenuation. Mean UV doses received in the mixed layer depth were higher by a factor 1.4-33 relative to doses received at fixed depths (5 and $10 \mathrm{~m}$ ) in summer (stratified period), while the inverse pattern was found in winter (mixing period). This shows the importance of taking into account the vertical mixing in the evaluation of UVR effects on marine organisms.
\end{abstract}

\section{INTRODUCTION}

Solar radiation strongly influences biogeochemical cycles and ecosystem functions in the ocean (1). Photosynthetically available radiation (PAR: 400-700 $\mathrm{nm}$ ) provides energy for photosynthesis, which is responsible for marine primary production and represents the main input of energy into marine ecosystems (2). In contrast, energetic ultraviolet radiation (UVR: $280-400 \mathrm{~nm}$ ) has numerous deleterious effects on a variety of marine organisms, including primary producers, heterotrophic bacteria, zooplankton and secondary consumers (1,3). Well-known UVR effects are inhibition of primary production and inhibition of bacterial production (4-7). UVR can affect plankton by inducing (1) direct damages to DNA, namely cyclobutane pyrimidine dimers (CPDs), by ultraviolet-B radiation (UVR-B: 280 to $315 \mathrm{~nm}$ ) or (2) oxidative damages to DNA, lipids and proteins via the generation of reactive oxygen

*Corresponding author email: richard.sempere@mio.osupytheas.fr (Richard Sempere species (ROs) by ultraviolet-A radiation (UVR-A: $315-400 \mathrm{~nm}$ ) (8). On the other hand, DNA damages can be repaired through photoenzymatic repairs (PERs) via the action of photolyase, induced by both UVR-A $(380 \mathrm{~nm})$ and PAR (9-11). Moreover, UVR impacts the carbon cycle by modifying the biological availability of dissolved organic matter (DOM) for bacterioplankton (12). The penetration depth, intensity and spectral distribution of solar radiation in the water column depend on the amount and quality of optically active seawater constituents or inherent optical properties (IOPs), and on the quality and intensity of the surface solar irradiance, which is strongly influenced by solar zenith angle (SZA), meteorological conditions and sea surface roughness. Also, the depth of the mixed layer $\left(Z_{\mathrm{m}}\right)$, i.e. the depth at which cells can be transported within the upper water column, is a key factor in assessing the actual impact of UVR on living organisms in surface marine waters (13).

Several IOPs contribute to the overall attenuation of PAR and UVR in the water column, including the absorption $[a(\lambda)]$ and backscattering $\left[b_{\mathrm{b}}(\lambda)\right]$ processes that concern the water itself $\left[a_{\mathrm{w}}(\lambda), b_{\mathrm{bw}}(\lambda)\right]$, the phytoplankton $\left[\left(a_{\mathrm{ph}}(\lambda), b_{\mathrm{bph}}(\lambda)\right]\right.$, the nonalgal particulate $\left[\left(a_{\mathrm{NAP}}(\lambda), \mathrm{b}_{\mathrm{bNAP}}(\lambda)\right]\right.$ and the chromophoric DOM $\left[a_{\mathrm{CDOM}}(\lambda)\right]$. The scattering contribution of CDOM is very small relative to the other terms and is usually neglected. The absorption and backscattering coefficients of pure water were recently re-assessed (14). Pure water absorbs very little blue light and absorbs higher amounts of red and UV radiation. Phytoplankton absorption varies significantly relative to community composition. Peaks are typically found in the PAR domain, at approximately 440 and $675 \mathrm{~nm}$ and are linked to total chlorophyll $a$ (TChl a) (15-18). Conversely, CDOM and NAP absorption increase steadily (exponentially) from PAR to UVR wavelengths (19-22). Therefore, in the ocean, while chromophoric detrital matter $(\mathrm{CDM}=\mathrm{CDOM}+\mathrm{NAP})$ is the major contributor to total absorption in the UV domain $(\sim 60-95 \%)$, in the blue region $(440-490 \mathrm{~nm})$, the contributions of CDM and phytoplankton tend to be equivalent ( 40-50\%) (23-26).

Due to its weak cloud cover, the Mediterranean atmosphere is characterized by higher solar radiation levels than those found at similar latitudes in the Atlantic Ocean (27-29) and by high seasonal variations in normalized water leaving radiances in the visible domain (30). The Mediterranean Sea, which is known as a low chlorophyll low nutrient (LNLC) oligotrophic system, is characterized by a blue color that does not extend as deep as predicted by 
its TChl $a$ content alone. This discrepancy between ocean color and TChl $a$ concentration was suggested to be attributed to either an "excessive" level of CDOM (31-35) or to the presence of Saharan dust in the upper layer (36). For a given TChl $a$ concentration, the amount of CDOM is systematically higher in the Mediterranean Sea than in the Atlantic and Pacific Oceans $(33,37)$. The higher amounts of CDOM in this semi-enclosed sea may be explained by important river discharges [for example, the relative fluvial load of total organic carbon (TOC) to the Mediterranean Sea is 8 to 30 times higher than that in other oceans] (38) and by the winter deep vertical mixing that occurs in the northern parts of the Mediterranean basins (33). Therefore, CDOM would significantly impact the attenuation of UVR and PAR in the Mediterranean Sea. Although the attenuation of PAR has been already documented offshore (39), very few data are available concerning the attenuation of UVR in Mediterranean surface waters (29).

The goals of this study are as follows: (1) to describe the temporal variability of CDOM absorption and spectral slope coefficients, (2) to assess the temporal variability of UVR and PAR surface irradiances as well as of their attenuation in the water column, (3) to examine the relationships between UVR and PAR attenuation and CDOM absorption and (4) to determine underwater UVR-B and UVR-A doses received at fixed depth and within the mixed layer to highlight the significant role of vertical mixing in the UVR effects on the marine organisms in the Northwestern Mediterranean Sea (Bay of Marseilles, France).

\section{MATERIALS AND METHODS}

Field measurements and sampling. Field measurements and water collection were performed monthly from November 2007 to December 2008 at the SOLEMIO coastal station $\left(5^{\circ} 17^{\prime} 30^{\prime \prime} \mathrm{E} ; 43^{\circ} 14^{\prime} 30^{\prime \prime} \mathrm{N} ; 60 \mathrm{~m}\right.$ depth) located in the Bay of Marseilles near the Frioul Islands ( $\sim 8 \mathrm{~km}$ off Marseilles) in the Northwestern Mediterranean Sea (Fig. 1). SOLEMIO is a nearshore observation site of the national Service d'Observation en Milieu LITtoral (SOMLIT; http://www.domino.u-bordeaux.fr/somlit_national/) and is sampled bi-monthly for hydrological and biogeochemical parameters for about 20 years. The field measurements, which included conductivity-temperature-depth (CTD) profiles, and atmospheric and in-water radiometric measurements, were conducted at solar noon under sunny and overcast skies and during low wind conditions on board the R/V Antédon II. Along with these measurements, discrete samples for TOC and CDOM analyses were collected at $2 \mathrm{~m}$ depth with a $4 \mathrm{~L}$

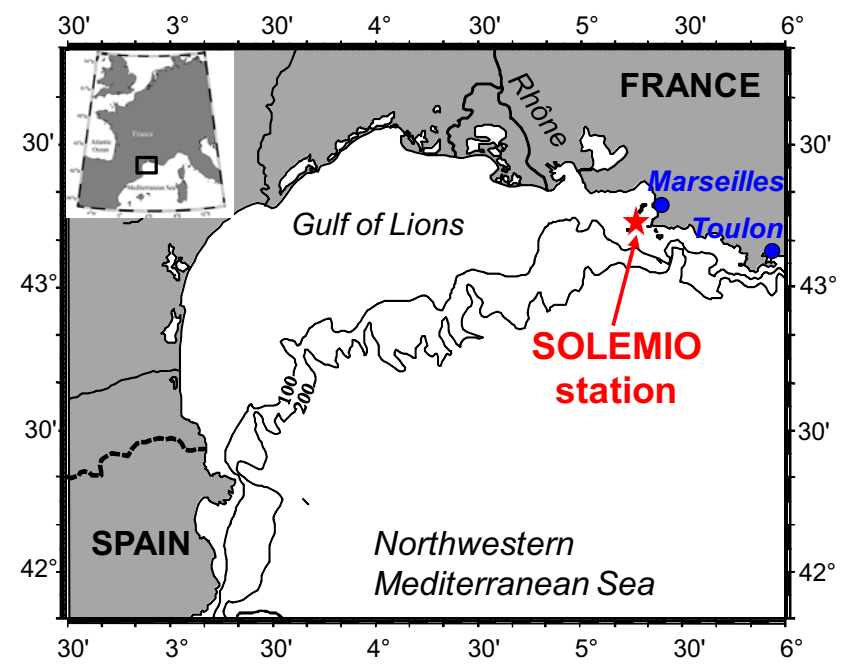

Figure 1. Location of the SOLEMIO station in the Northwestern Mediterranean Sea (Bay of Marseilles, France).
Niskin bottle that was equipped with silicon ribbons and Viton o-rings to minimize organic carbon contamination. In situ temperature, salinity, TChl $a$ concentrations and turbidity profiles were obtained with a 19plus SeaBird Electronics CTD instrument that was equipped with a WETStar Chla fluorometer (WETLabs, Inc.) and an STM turbidity meter (Seapoint, Inc.). Mixed layer depth $\left(Z_{\mathrm{m}}\right.$ in $\left.\mathrm{m}\right)$ was determined from the CTD profiles. It corresponded to the average of the depth at which the density difference with that of surface reached $0.1 \mathrm{~kg} \mathrm{~m}^{-3}$. The aerosol optical depth (AOD) at $440 \mathrm{~nm}$ at solar noon was estimated by the automatic sunphotometer of the PHOTONS network (French part of the AERONET network operated by the LOA) (40) installed in Toulon, which is the closest station from Marseilles (Fig. 1). The sunphotometer is calibrated every year and the AOD is derived with an uncertainty of \pm 0.01 (41).

Two consecutive profiles of downward irradiance $\left[E_{\mathrm{d}}(Z, \lambda)\right.$ in $\mu \mathrm{W} \mathrm{cm}{ }^{-2}$ ] were conducted at solar noon with a MicroPro free-fall profiler (Satlantic, Inc.) that was equipped with pressure, temperature and tilt sensors and OCR-504 downward irradiance sensors for the UVR-B (305 nm), UVR-A (325, 340 and $380 \mathrm{~nm})$ and PAR (412, 443, 490 and $565 \mathrm{~nm})$ spectral domains $(42,43)$. Surface irradiance $\left[E_{\mathrm{s}}(\lambda)\right.$ in $\mu \mathrm{W} \mathrm{cm}{ }^{-2}$, which is equivalent to the downward irradiance just above the sea surface $\left[E_{\mathrm{d}}\left(0^{+}, \lambda\right)\right]$, was simultaneously measured in the same channels from the ship deck with other OCR-504 downward irradiance sensors (surface reference). These measurements were made to account for the variations in cloud conditions that occurred during measurement. For the in-water sensors, the full width at half maximum (FWHM) of the wavelengths was $2 \mathrm{~nm}$ for 305, 325, and $340 \mathrm{~nm}$ and $10 \mathrm{~nm}$ for 380 , 412, 443, 490, and $565 \mathrm{~nm}$. For the in-air sensors, the FWHM was $2 \mathrm{~nm}$ for 305,325 and $340 \mathrm{~nm}, 10 \mathrm{~nm}$ for $380 \mathrm{~nm}$ and $20 \mathrm{~nm}$ for 412,443 , 490 and $565 \mathrm{~nm}$. The cosine response accuracy for downward UV irradiance from $0-60^{\circ}$ was $4 \%$ and $8 \%$ for the in-air and in-water sensors respectively. Similarly, the cosine response accuracy for downward visible irradiance from $0-60^{\circ}$ was $3 \%$ for both sensors. The typical noise equivalent irradiances were $1.5 \cdot 10^{-3}$ (UVR-B), 4.5.10 $0^{-3}$ (UVR-A) and $2.5 .10^{-3} \mu \mathrm{W} \mathrm{cm}{ }^{-2}$ (PAR). The profiler was operated at a sampling rate of $7 \mathrm{~Hz}$ (sampling resolution of $10 \mathrm{~cm}$ ) from the rear of the ship and was deployed $30 \mathrm{~m}$ from the ship to minimize the shadowing and disturbance effects of the ship. Each cast was accompanied by a measurement of the dark current (instrument on the deck) and a pressure tare (instrument at sea surface). The free-fall descent rate of the profiler ranged from 0.5 to $0.8 \mathrm{~m} \mathrm{~s}^{-1}$. The surface reference was set up at the top of the mast of the ship ( $\sim 10 \mathrm{~m}$ above water) to avoid shadowing or reflecting obstacles. Calibration of the in-air and in-water irradiance sensors was conducted by Satlantic just before this study.

Radiometric data processing and determination of $K_{\mathrm{d}}(\lambda)$ and underwater doses. Radiometric measurements were logged with Satlantic's Satview 2.6 software, and the data were prepared and processed with the Satlantic's ProSoft 7.6 software. The ProSoft software was used for initial data processing, such as radiometric calibration, dark correction, immersion coefficient and pressure tare calculations and the removal of data with a tilt $>5^{\circ}$. The data interpolation option of the software was not used to avoid smoothing the raw radiometric data.

Vertical diffuse attenuation coefficients for downward irradiance $\left[K_{\mathrm{d}}(\lambda)\right.$ in $\left.\mathrm{m}^{-1}\right]$ were calculated from homogeneous surface water masses from the $E_{\mathrm{d}}(Z, \lambda)$ data by using either the standard method, i.e. $K_{\mathrm{d}}(\lambda)$ calculated from the slope of the linear regression of the log-transformed downward irradiance $v s$ depth (Eq. 1), or the method of Zaneveld (44). The Zaneveld method was used when variation of irradiance values were higher than $100 \%$ over $\mathrm{ca} .70 \mathrm{~cm}$ in near-surface waters. For the standard method, we applied the formula:

$$
E_{\mathrm{d}}(Z, \lambda)=E_{\mathrm{d}}\left(0^{-}, \lambda\right) e^{-K_{\mathrm{d}}(\lambda) Z}
$$

where $E_{\mathrm{d}}\left(0^{-}, \lambda\right)$, the downward irradiance beneath the sea surface, was theoretically computed from deck measurements by using the following formula (45):

$$
E_{\mathrm{d}}\left(0^{-}, \lambda\right)=\frac{E_{\mathrm{d}}\left(0^{+}, \lambda\right)}{(1+\alpha)}
$$

where $\alpha$ is the Fresnel reflection albedo for irradiance from the sun and sky computed from a 'look up table' available online at http://wwwcave.larc.nasa.gov/cave/ $(46,47)$. $\alpha$ values ranged from 0.045 to 0.114 . 
$K_{\mathrm{d}}(\lambda)$ was calculated for a depth range of $0-5 \mathrm{~m}$ to $0-30 \mathrm{~m}$ depended on the wavelengths. In the Zaneveld method, $K_{\mathrm{d}}(\lambda)$ was determined from the upward integration of $E_{\mathrm{d}}(Z, \lambda)$ beginning at the focal depth $\left(Z_{0}, \mathrm{~m}\right)$. At this point, wave focusing is not considered to affect the irradiance profile at successively shallower depths, as shown in the following formula:

$$
I^{\prime}(Z, \lambda)=\int_{Z_{0}}^{Z} E_{\mathrm{d}}(Z, \lambda) \mathrm{d} Z
$$

where the slope of $\ln \frac{\mathrm{d} I^{\prime}(Z)}{\mathrm{d} Z}$ is $K_{\mathrm{d}}(\lambda)$. The method for determining $Z_{0}$ was to assess how much the following point (depth) changes the $K_{\mathrm{d}}(\lambda)$ calculation. If adding the next depth $(Z+1)$ changed $K_{\mathrm{d}}(\lambda, Z)$ by less than $5 \%$, then $Z_{0}$ was reached. In our study, $Z_{0}$ ranged from 5 to $9.5 \mathrm{~m}$. The coefficients of variation $(\mathrm{CV})$ for mean $K_{\mathrm{d}}(\lambda)$ derived from the two irradiance profiles were less than $6 \%$.

The depth of the euphotique zone $\left(Z_{\text {eu }}\right.$ in $\left.\mathrm{m}\right)$, defined as the depth where the PAR is reduced to $1 \%$ of its surface value, was determined using the formula:

$$
Z_{\text {eu }}=\frac{\ln (100)}{K_{\mathrm{d}}(\mathrm{PAR})}
$$

where $K_{\mathrm{d}}(\mathrm{PAR})\left(\mathrm{in}^{-1}\right)$ is the vertical diffuse attenuation coefficient for downward irradiance in the spectral range of PAR. $K_{\mathrm{d}}(\mathrm{PAR})$ was computed as decribed above for $K_{\mathrm{d}}(\lambda)$ from downward irradiances in the spectral range of PAR $\left[E_{\mathrm{d}}(Z\right.$, PAR $)$ in quanta $\left.\mathrm{cm}^{-2} \mathrm{~s}^{-1}\right] . E_{\mathrm{d}}(\mathrm{Z}, \mathrm{PAR})$ was estimated from the four visible channels using Satlantic's Prosoft software. $E_{\mathrm{d}}(Z, \lambda)$ was first interpolated onto an $1 \mathrm{~nm}$ interval from 400 to $700 \mathrm{~nm}$ and then integrated using the formula:

$$
E_{\mathrm{d}}(Z, \mathrm{PAR})=\int_{400 \mathrm{~nm}}^{700 \mathrm{~nm}} \frac{\lambda}{\mathrm{hc}} E_{\mathrm{d}}(Z, \lambda) \mathrm{d} \lambda
$$

where $\lambda$ is the wavelength $(\mathrm{nm}), \mathrm{h}$ is the Planck's constant $\left(6.63 .10^{-34} \mathrm{~J} \mathrm{~s}\right), c$ is the speed of light in the vacuum $\left(3.10^{8} \mathrm{~m} \mathrm{~s}^{-1}\right)$ and $\mathrm{E}_{\mathrm{d}}(\mathrm{Z}, \lambda)$ is the downward irradiance at depth $\mathrm{Z}$.

We determined UVR-B and UVR-A doses received beneath the sea surface $\left[H\left(0^{-}, \lambda\right)\right]$, at 5 and $10 \mathrm{~m}$ into the water column $[H(5, \lambda) H(10$ $\lambda)$ in $\mathrm{kJ} \mathrm{m}^{-2}$ ] as well as the mean UVR-B and UVR-A doses received within the mixed layer $\left[H(\mathrm{~m}, \lambda)\right.$ in $\left.\mathrm{kJ} \mathrm{m}^{-2}\right] . H(Z, \lambda)$ was assessed using the following formula:

$$
H(Z, \lambda)=H\left(0^{-}, \lambda\right) e^{-K_{\mathrm{d}}(\lambda) Z}
$$

where $H\left(0^{-}, \lambda\right)$ is the dose beneath the sea surface, $K_{\mathrm{d}}(\lambda)$ is the vertical diffuse attenuation coefficient for downward irradiance and $Z$ is 5 or $10 \mathrm{~m}$. On the other hand, $H(\mathrm{~m}, \lambda)$ was evaluated using an equation, taking into account the mixed layer depth $(47,48)$ :

$$
H(m, \lambda)=\frac{H\left(0^{-}, \lambda\right)\left(1-e^{-K_{\mathrm{d}}(\lambda) Z_{\mathrm{m}}}\right)}{K_{\mathrm{d}}(\lambda) \times Z_{\mathrm{m}}}
$$

where $Z_{\mathrm{m}}$ is the mixed layer depth. $H\left(0^{-}, \lambda\right)$ was obtained by integrating downward irradiance beneath the sea surface $\left[E_{\mathrm{d}}\left(0^{-}, \lambda\right)\right.$, in $\left.\mu \mathrm{W} \mathrm{cm}{ }^{-2}\right]$ over the exposure period:

$$
H\left(0^{-}, \lambda\right)=\sum E_{\mathrm{d}}\left(0^{-}, \lambda\right) \Delta t
$$

Although radiometric measurements were conducted only at solar noon for about $20 \mathrm{~min}$, we integrated the mean $E_{\mathrm{d}}\left(0^{-}, \lambda\right)$ values during $2 \mathrm{~h}$ to compute underwater doses $\left[H\left(0^{-}, \lambda\right), H(5, \lambda), H(10, \lambda)\right.$ and $H(\mathrm{~m}$, 2)] quite representative of those actually received during $2 \mathrm{~h}$ around solar noon. For UVR-B and UVR-A, we chose the wavelengths 305 and $380 \mathrm{~nm}$, respectively. The wavelength $305 \mathrm{~nm}$ is used as biologically effective wavelength for the induction of DNA damages (CPDs), while
$380 \mathrm{~nm}$ is used as biologically effective wavelength for the induction of photorepairs (PERs) $(8-11,49)$. We finally determined the Q factor (in $\%$ ), which corresponds to the ratio (in \%) of the dose at 305 to $380 \mathrm{~nm}$. The $\mathrm{Q}$ factor is used as an index of the importance of CPDs relative to PERs (47).

CDOM and TOC analyses. Samples were filtered immediately after collection, in dim light, using $0.2 \mu \mathrm{m}$ Millipore filters prerinsed with Milli-Q water. Filtered samples were stored in the dark at $4^{\circ} \mathrm{C}$ until analyses, conducted within $24 \mathrm{~h}$. CDOM absorbance measurements were performed from 275 to $700 \mathrm{~nm}$ with an Ultrapath multiple pathlength, liquid core waveguide system (MPLCW, World Precision Instruments, Inc.). Absorbance spectra were obtained with the longest pathlength $(2 \mathrm{~m}$ length) and with a filtered reference salt solution prepared with Milli-Q water and precombusted $\mathrm{NaCl}$ (Sigma). This method reproduced the refractive index of the samples to minimize the baseline offsets in the absorption spectra (50). Reference salt solutions and samples were brought to room temperature before analysis. The sample cell was flushed with successively diluted detergent (cleaning solution concentrate, WPI Inc.), high reagent grade $\mathrm{MeOH}, 2 \mathrm{M} \mathrm{HCl}$ and Milli-Q water between each sample. Trapped microbubbles were minimized by using a peristaltic pump to draw the sample into the sample cell. Precision of Ultrapath measurements was $\pm 1.6 \%$ at $280 \mathrm{~nm}, \pm 1.9 \%$ at $300 \mathrm{~nm}, \pm 3.1 \%$ at $400 \mathrm{~nm}$ and $\pm 0.2 \%$ at $500 \mathrm{~nm}$. The CDOM absorption coefficients, $a_{\mathrm{CDOM}}(\lambda)\left(\mathrm{m}^{-1}\right)$, were determined by using the following relationship:

$$
a_{\mathrm{CDOM}}(\lambda)=\frac{2.303 A(\lambda)}{L}
$$

where $A(\lambda)$ is the absorbance at wavelength $\lambda$ (dimensionless) and $L$ is the pathlength $(\mathrm{m})$. Spectral slope coefficient, $S\left(\mathrm{~nm}^{-1}\right)$, was computed according to the equation:

$$
a_{\mathrm{CDOM}}(\lambda)=a_{\mathrm{CDOM}}\left(\lambda_{0}\right) \times e^{-S\left(\lambda-\lambda_{0}\right)}
$$

where $a_{\mathrm{CDOM}}(\lambda)$ is the absorption coefficient at the wavelength $\lambda$, $a_{\mathrm{CDOM}}\left(\lambda_{0}\right)$ is the absorption coefficient at reference wavelength $\lambda_{0}$ and $\mathrm{S}$ is the spectral slope coefficient in the spectral range from $\lambda_{0}$ to $\lambda$ (with $\left.\lambda_{0}<\lambda\right)$. Three spectral ranges were used for the $S$ calculation: 290$500 \mathrm{~nm}\left(S_{290-500}\right), 275-295 \mathrm{~nm}\left(S_{275-295}\right)$ and $350-400 \mathrm{~nm}\left(S_{350-400}\right)$. The slope ratio $\left(S_{R}\right)$ was calculated as the ratio of $S_{275-295}$ to $S_{350-400}$ as described by Helms et al. (51). $S_{290-500}$ and $S_{350-400}$ were determined by applying a nonlinear (exponential) least-squares fit on the raw $a_{\mathrm{CDOM}}(\lambda)$ data, while $S_{275-295}$ was obtained by applying a linear least-squares fit to the log-transformed $a_{\mathrm{CDOM}}(\lambda)$ data. The mean determination coefficients $\left(R^{2}\right)$ of the least-squares fits were $\sim 0.99$.

Samples were acidified and analyzed for TOC by using a TOC-5000 total carbon analyzer (52). The accuracy of the instrument and the system blank were determined by analyzing reference materials (D. Hansell, Rosenstiel School of Marine and Atmospheric Science, Miami, USA), including the Deep Atlantic Water (DAW) and low carbon water (LCW) reference materials. The average DOC concentrations in the DAW and $\mathrm{LCW}$ reference standards were $45 \pm 2 \mu \mathrm{M} \mathrm{C}, n=24$ and $1 \pm 0.3 \mu \mathrm{M}$ $\mathrm{C}, n=24$ respectively. The nominal analytical precision of the procedure was within $2 \%$.

\section{RESULTS AND DISCUSSION}

\section{Atmospheric, hydrological and biogeochemical characteristics}

Measurements were conducted under sunny sky except for 3 days (06/05, 23/09 and 04/12/08) for which an overcast sky was encountered (Table 1). For sunny days, SZA ranged from $22^{\circ}(10 / 07 / 08)$ to $67^{\circ}(19 / 12 / 07)$. AOD at $440 \mathrm{~nm}$ varied from $0.06(25 / 11 / 08)$ to $0.55(06 / 05 / 08)$. Seawater temperature at $2 \mathrm{~m}$ depth was as low as $13.2^{\circ} \mathrm{C}$ in February and reached $22.2^{\circ} \mathrm{C}$ in September. Salinity at $2 \mathrm{~m}$ depth was in the range 37.9-38.4 psu, except on $06 / 05$ and 23/06/08 where it was 37.1 and 37.5 psu respectively (Table 1). These lower salinities have been attributed to the intrusion of Rhône River freshwater lenses in 
Table 1. Sampling dates, atmospheric conditions (sky, SZA, AOD at $440 \mathrm{~nm}$ ), hydrological conditions $\left(\mathrm{T}, \mathrm{S}, Z_{\mathrm{m}}\right)$ and biogeochemical conditions $\left(Z_{\mathrm{eu}}\right.$, TChl $a$, turbidity, TOC) at the SOLEMIO station (Bay of Marseilles, Northwestern Mediterranean Sea).

\begin{tabular}{|c|c|c|c|c|c|c|c|c|c|c|}
\hline Date & $\begin{array}{c}\text { Sky } \\
\text { condition }\end{array}$ & SZA $\left(^{\circ}\right)$ & $\begin{array}{l}\text { AOD at } \\
440 \mathrm{~nm}\end{array}$ & $T^{*, \dagger}\left({ }^{\circ} \mathrm{C}\right)$ & $S^{*, \dagger}(\mathrm{psu})$ & $Z_{\mathrm{m}}(\mathrm{m})$ & $Z_{\mathrm{eu}}(\mathrm{m})$ & {$[\mathrm{TChl} a]^{*, \dagger}\left(\mu \mathrm{g} \mathrm{L}^{-1}\right)$} & Turbidity*, ${ }^{\dagger}$ (FTU) & {$[\mathrm{TOC}]^{*}(\mu \mathrm{M})$} \\
\hline $07 / 11 / 07$ & Sunny & 61 & 0.19 & 17.8 & 38.1 & 50 & 44 & na & na & 68 \\
\hline $19 / 12 / 07$ & Sunny & 67 & 0.09 & 14.4 & 38.2 & 50 & 54 & na & na & 60 \\
\hline 05/02//08 & Sunny & 63 & 0.12 & 13.2 & 38.1 & 50 & 42 & 0.9 & na & 55 \\
\hline $14 / 02 / 08$ & Sunny & 59 & 0.28 & 13.2 & 38.1 & 50 & 44 & 0.2 & na & 78 \\
\hline $26 / 03 / 08$ & Sunny & 41 & 0.12 & 12.8 & 38.1 & 9 & 42 & 0.2 & 0.7 & 56 \\
\hline $29 / 04 / 08$ & Sunny & 30 & 0.20 & 14.5 & 38.1 & 28 & 47 & 0.9 & 4.8 & 70 \\
\hline $06 / 05 / 08$ & Overcast & na & 0.55 & 16.1 & 37.1 & 6 & 44 & 1.6 & 5.3 & 65 \\
\hline $23 / 06 / 08$ & Sunny & 26 & 0.14 & 21.4 & 37.5 & 6 & 51 & 1.4 & 7.7 & 79 \\
\hline $10 / 07 / 08$ & Sunny & 22 & 0.14 & 18.6 & 37.9 & 6 & 54 & 0.2 & 0.6 & 67 \\
\hline $23 / 09 / 08$ & Overcast & na & na & 22.2 & 38.4 & 13 & 64 & 0.4 & 3.9 & 72 \\
\hline $14 / 10 / 08$ & Sunny & 52 & 0.49 & 19.4 & 38.2 & 37 & 55 & 0.3 & 0.1 & 70 \\
\hline $25 / 11 / 08$ & Sunny & 64 & 0.06 & 15.3 & 38.2 & 50 & 37 & 0.6 & 4.8 & 55 \\
\hline $04 / 12 / 08$ & Overcast & na & 0.11 & 16.1 & 38.1 & 50 & 52 & 0.8 & 5.5 & 63 \\
\hline
\end{tabular}

SZA, solar zenith angle; AOD, aerosol optical depth; $T$, temperature; $S$, salinity; $Z_{\mathrm{m}}$, mixed layer depth; $Z_{\mathrm{eu}}$, depth of the euphotique zone; [TChl $a$ ], total chlorophyll $a$ concentration; [TOC], total organic carbon concentration; psu, practical salinity unit; FTU, formazin turbidity unit; na, not available. *Measured at 2 m depth. ${ }^{\dagger}$ Measured from CTD profiles.

the Bay of Marseilles (53-55). The water column was quite well stratified in spring and summer $\left(Z_{\mathrm{m}}\right.$ ranging from 6 to $\left.13 \mathrm{~m}\right)$, except on $29 / 04 / 08\left(Z_{\mathrm{m}}=28 \mathrm{~m}\right)$, whereas it was strongly mixed in autumn and winter periods $\left(Z_{\mathrm{m}}: \sim 50 \mathrm{~m}\right)$. $Z_{\mathrm{eu}}$ varied from $37 \mathrm{~m}(25 / 11 / 08)$ to $64 \mathrm{~m} \mathrm{(23/09/08)}$ (Table 1). TChl $a$ concentration, turbidity (acquired from CTD profiles) and TOC concentration at $2 \mathrm{~m}$ depth ranged from 0.2 to $1.6 \mu \mathrm{g} \mathrm{L} \mathrm{L}^{-1}$, from 0.1 to 7.7 FTU and from 55 to $79 \mu \mathrm{M} \mathrm{C}$, respectively, the highest values being observed on $06 / 05 / 08$ or on $23 / 06 / 08$, i.e. during the freshwater intrusion events. Indeed, it has been shown that these Rhône River freshwater lenses, enriched in nutrients, enhanced the phytoplankton biomass accumulation in the Bay of Marseilles, leading to an increase in particulate matter and organic carbon (53)

\section{Temporal variability of CDOM}

CDOM absorption at $350 \mathrm{~nm}\left[a_{\mathrm{CDOM}}(350)\right]$ was chosen to describe the changes in CDOM quantity. During the study period, $a_{\mathrm{CDOM}}(350)$ ranged from $0.069 \mathrm{~m}^{-1}(23 / 09 / 08)$ to $0.133 \mathrm{~m}^{-1}(06 / 05 / 08)$ (Table 2). The relatively high $a_{\mathrm{CDOM}}(350)$ observed on $06 / 05 / 08$ and on 23/06/08 (0.133 and $0.123 \mathrm{~m}^{-1}$ respectively) may be related to the Rhône River freshwater intrusions and the subsequent enhancement of the phytoplankton biomass accumulation (53). By contrast, the relatively high $a_{\mathrm{CDOM}}(350)$ recorded on $25 / 11 / 08\left(0.128 \mathrm{~m}^{-1}\right)$ when a strong vertical mixing occurred $\left(Z_{\mathrm{m}}=50 \mathrm{~m}\right.$; Table 1$)$ may be due to the input of deeper CDOM in the surface waters. The $a_{\mathrm{CDOM}}(350)$ values measured here in the surface waters of the Bay of Marseilles are in the lowest range of $a_{\mathrm{CDOM}}(350)$ values reported for coastal waters (56-59). These values are closer to those encountered in the open ocean $(26,60,61)$. Our relatively low CDOM absorptions (for coastal waters) are consistent with the "low" TOC concentrations measured (55-79 $\mu \mathrm{M}$ C; Table 1) and with the fact that the Bay of Marseilles is not under the direct influence of terrestrial DOM inputs, although, as mentioned above, sporadic intrusions of Rhône River freshwater lenses may stimulate the marine productivity through nutrient enrichments.

The spectral slope coefficients, $S_{290-500}, S_{275-295}$ and $S_{350-400}$, varied in the ranges $0.015-0.032,0.020-0.039$ and $0.015-$
$0.025 \mathrm{~nm}^{-1}$, respectively (Table 2). The highest values were found from June to September when the water column was quite well stratified $\left(Z_{\mathrm{m}}: 6-13 \mathrm{~m}\right.$; Table 1$)$ and the UVR and PAR surface irradiances were the most important (see paragraph 3.3), which highlights a CDOM photobleaching process in summer. Indeed, increases in spectral slope coefficients including $S_{250-650}, S_{275-295}, S_{280-312}, S_{290-350}, S_{300-700}, S_{320-400}$ and $S_{350-500}$ in various coastal and open ocean environments have been ascribed to a decrease in the molecular weight and aromaticity of CDOM due to photobleaching and/or to a shift in the nature of organic matter, from terrestrial to marine (frequently observed via an increase in salinity) (51,56,61-66). For instance, in the frame of a 2-year time-series, Organelli et al. (67) reported in the surface waters of the BOUSSOLE site (Northwestern Mediterranean Sea) $S_{350-500}$ very close to our $S_{350-400}$ (i.e. $\left.0.014-0.022 \mathrm{~nm}^{-1}\right)$, with, in the same way, the highest values recorded in summer as the result of photobleaching. Conversely, we observed the lowest $S_{290-500}, S_{275-295}$ and $S_{350-400}$ on 25/11/ 08 or $04 / 12 / 08$ (Table 2) during the strong vertical mixing $\left(Z_{\mathrm{m}}=50 \mathrm{~m}\right.$; Table 1), which emphasizes the input of deeper CDOM, very likely of higher molecular weight and of higher aromaticity, in the surface waters as proposed by Para et al. (53).

The $S_{275-295} / S_{350-400}$ ratio $\left(S_{\mathrm{R}}\right)$ varied from $1.2(04 / 12 / 08)$ to $2.1(25 / 11 / 08)$ (Table 2). Even though in this work $S_{\mathrm{R}}$ cannot be used as index of photobleaching (if it was the case, the highest values would be observed in the summer), it allows to show that $\mathrm{CDOM}$ is clearly of marine origin and not of terrestrial origin. According to Helms et al. (51) and Pavlov et al. (68), $S_{\mathrm{R}}<1$ is indicative of terrestrial matter while $S_{\mathrm{R}}>1$ is representative of marine CDOM. Interestingly, the three spectral slope coefficients co-varied linearly and positively $\left(R^{2}=0.51-0.93, \quad n=12\right.$, $P<0.01), S_{275-295}$ being systematically higher than $S_{290-500}$ and $S_{350-400}$. This suggests that in the surface waters of the Bay of Marseilles, the CDOM absorption spectra did not present a constant spectral slope coefficient but steeper slope coefficients towards the short UV wavelengths, as it has been observed for the South East Pacific waters (42). Due to our very low ranges of salinity, CDOM absorption coefficients and TOC concentrations, no significant relationship was ascertained between these parameters and the three spectral slope coefficients. 
Table 2. CDOM absorption and spectral slope coefficients determined on samples collected at $2 \mathrm{~m}$ depth at the SOLEMIO station (Bay of Marseilles, Northwestern Mediterranean Sea).

\begin{tabular}{lccccc}
\hline Date & $\begin{array}{c}a_{\mathrm{CDOM}}(350) \\
\left(\mathrm{m}^{-1}\right)\end{array}$ & $\begin{array}{c}S_{290-500} \\
\left(\mathrm{~nm}^{-1}\right)\end{array}$ & $\begin{array}{c}S_{275-295} \\
\left(\mathrm{~nm}^{-1}\right)\end{array}$ & $S_{350-400}\left(\mathrm{~nm}^{-1}\right)$ & $S_{\mathrm{R}}$ \\
\hline $07 / 11 / 07$ & 0.107 & 0.021 & na & 0.017 & na \\
$19 / 12 / 07$ & 0.098 & 0.019 & 0.029 & 0.017 & 1.7 \\
$05 / 02 / / 08$ & 0.106 & 0.017 & 0.023 & 0.016 & 1.4 \\
$14 / 02 / 08$ & 0.086 & 0.020 & 0.032 & 0.017 & 1.9 \\
$26 / 03 / 08$ & 0.096 & 0.018 & 0.031 & 0.016 & 1.9 \\
$29 / 04 / 08$ & 0.112 & 0.019 & 0.028 & 0.018 & 1.6 \\
$06 / 05 / 08$ & 0.133 & 0.019 & 0.031 & 0.019 & 1.6 \\
$23 / 06 / 08$ & 0.123 & 0.032 & 0.037 & 0.025 & 1.5 \\
$10 / 07 / 08$ & 0.091 & 0.026 & 0.036 & 0.022 & 1.6 \\
$23 / 09 / 08$ & 0.069 & 0.023 & 0.039 & 0.021 & 1.9 \\
$14 / 10 / 08$ & 0.088 & 0.020 & 0.037 & 0.018 & 2.1 \\
$25 / 11 / 08$ & 0.128 & 0.015 & 0.022 & 0.015 & 1.5 \\
$04 / 12 / 08$ & 0.112 & 0.018 & 0.020 & 0.017 & 1.2 \\
& & & & &
\end{tabular}

na: not available (CDOM spectrum acquired from 290 to $700 \mathrm{~nm}) . S_{\mathrm{R}}=S_{275-295} / S_{350-400}$.

\section{Temporal variability of UVR and PAR surface irradiances}

$E_{\mathrm{s}}(\lambda)$ presented a large temporal variability, with as expected, the lowest values recorded in December (04/12/08; from $0.15 \mu \mathrm{W} \mathrm{cm}{ }^{-2}$ at $305 \mathrm{~nm}$ to $30 \mu \mathrm{W} \mathrm{cm}{ }^{-2}$ at $\left.490 \mathrm{~nm}\right)$ and the highest values recorded in June and July (23/06 and 10/07/08; from $4.6 \mu \mathrm{W} \mathrm{cm}$ c $^{-2}$ at $305 \mathrm{~nm}$ to $159 \mu \mathrm{W} \mathrm{cm}$ cm $^{-2}$ at $490 \mathrm{~nm}$ ) (Fig. 2). The important decreases in surface irradiance occurring on $06 / 05 / 08$ and $23 / 09 / 08$ were due to strong cloud covers. The UVR surface irradiances that were measured in this study in the summer under a clear sky (from $4.6 \mu \mathrm{W} \mathrm{cm}{ }^{-2}$ at $305 \mathrm{~nm}$ to $78 \mu \mathrm{W} \mathrm{cm}{ }^{-2}$ at $380 \mathrm{~nm}$ ) were higher than those recorded in Southern Spain $\left(36^{\circ} 52^{\prime} \mathrm{N}, 2^{\circ} 12^{\prime} \mathrm{W}\right)$ in September 1996 with the same type of narrowband radiometer (from $1.3 \mu \mathrm{W} \mathrm{cm}{ }^{-2}$ at $305 \mathrm{~nm}$ to $74 \mu \mathrm{W} \mathrm{cm}{ }^{-2}$ at $380 \mathrm{~nm}$ ) (69) and were also higher than those measured in the northern Baffin Bay from April 1998 through September 1999 (from $0.80 \mu \mathrm{W} \mathrm{cm}{ }^{-2}$ at $305 \mathrm{~nm}$ to $22 \mu \mathrm{W} \mathrm{cm}{ }^{-2}$ at $380 \mathrm{~nm}$ ) (70) and in the Beaufort Sea in JulyAugust 2009 (from $0.13 \mu \mathrm{W} \mathrm{cm}{ }^{-2}$ at $305 \mathrm{~nm}$ to $9.79 \mu \mathrm{W} \mathrm{cm}{ }^{-2}$ at $380 \mathrm{~nm}$ ) (43). In contrast, our UVR irradiances were lower than those acquired from the Malaysian peninsula $\left(2^{\circ} 49^{\prime}-\right.$ $5^{\circ} 12^{\prime} \mathrm{N}, \quad 104^{\circ} 09^{\prime}-103^{\circ} 16^{\prime} \quad \mathrm{W}$ ) in August 2007 (from

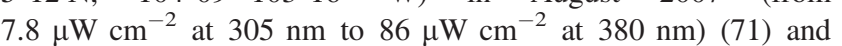
from the South Pacific Gyre $\left(25^{\circ} 54^{\prime} \mathrm{S}, 114^{\circ} \mathrm{W}\right)$ during the summer 2004 (from $9.8 \mu \mathrm{W} \mathrm{cm}{ }^{-2}$ at $305 \mathrm{~nm}$ to $98 \mu \mathrm{W} \mathrm{cm}{ }^{-2}$ at $380 \mathrm{~nm})(72)$.

The $E_{\mathrm{s}}(340) / E_{\mathrm{s}}(490)$ ratio did not display great variation during the year, ranging from $0.28(25 / 11 / 08)$ to $0.40(06 / 05$ and 23/09/08) (Fig. 3). On the contrary, the $E_{\mathrm{s}}(305) / E_{\mathrm{s}}(340)$ and $E_{\mathrm{s}}(305) / E_{\mathrm{s}}(490)$ ratios varied by a factor $\sim 10(0.008-0.82$ and $0.003-0.03$, respectively) between the dates $19 / 12 / 07$ and $23 / 06 /$ 08 (Fig. 3). These ratios indicated that UVR-A and PAR evolved similarly during the year. In contrast, the UVR-B increased 10 to 12 fold more than its UVR-A and PAR counterparts during the summer. Such temporal evolution of UVR irradiances and ratios has been reported by Seckmeyer et al. (28). The strong temporal variability of UVR-B may be explained by its higher dependence on direct/diffuse irradiance ratios than UVR-A and PAR. The significant inverse relationships observed between the $E_{\mathrm{s}}(305) / E_{\mathrm{s}}(340)\left(R^{2}=0.91, n=14, P<0.001\right)$ and $E_{\mathrm{s}}(305) / E_{\mathrm{s}}(490)$ ratios $\left(R^{2}=0.93, n=14, P<0.001\right)$ and the
SZA reinforced this explanation. It is worth noting that no relationships were observed between the surface irradiances and AOD at $440 \mathrm{~nm}$, even considering only data for which SZA was similar.

\section{Temporal variability of UVR and PAR attenuation in surface waters and relationships with $\mathrm{CDOM}$}

The lowest $K_{\mathrm{d}}(305)\left(0.214 \mathrm{~m}^{-1}\right)$ was observed in winter (on 05/ $02 / 08)$, while the lowest $K_{\mathrm{d}}(325-525)\left(0.044-0.215 \mathrm{~m}^{-1}\right)$ were recorded at the end of summer (on 23/09/08) (Fig. 4). While $\mathrm{a}_{\mathrm{CDOM}}(350)$ was averaged on $05 / 02 / 08\left(0.106 \mathrm{~m}^{-1}\right.$; Table 2$)$, it displayed the lowest value on 23/09/08 (0.069 $\mathrm{m}^{-1}$; Table 2), associated with quite high spectral slope coefficients $(0.023$, 0.039 and $0.021 \mathrm{~nm}^{-1}$ for $S_{290-500}, S_{275-295}$ and $S_{350-400}$, respectively; Table 2). Hence, the low $K_{\mathrm{d}}(\lambda)$ obtained at the end of summer and in winter were very likely related to CDOM photobleaching (end of summer) and to a lower biological production (end of summer and winter). The highest $K_{\mathrm{d}}(305-380)$ were recorded during the two episodic Rhône River plume intrusion events $\left(06 / 05\right.$ and 23/06/08; from $0.170 \mathrm{~m}^{-1}$ at $380 \mathrm{~nm}$ to $0.484 \mathrm{~m}^{-1}$ at $305 \mathrm{~nm}$ ) (Fig. 4), which also presented high $a_{\text {CDOM}}(350)$ (0.133 and $0.123 \mathrm{~m}^{-1}$; Table 2). Similar increase in $K_{\mathrm{d}}(305-380)$ has been reported for coastal Arctic Beaufort Sea in relation with Mackenzie River intrusions (43). However, the highest $K_{\mathrm{d}}(412-565)$ were measured after the entire water column was mixed from twelve consecutive days of Mistrals' wind (25/11/08; from $0.083 \mathrm{~m}^{-1}$ at $490 \mathrm{~nm}$ to $0.140 \mathrm{~m}^{-1}$ at $565 \mathrm{~nm}$; $\left.Z_{\mathrm{m}}: 50 \mathrm{~m}\right)$ (Fig. 4). Interestingly $a_{\mathrm{CDOM}}(350)$ was also high at this date $\left(0.128 \mathrm{~m}^{-1}\right.$; Table 2$)$. Therefore, $K_{\mathrm{d}}(\lambda)$ increased at the beginning of the stratification period (March-June; $Z_{\mathrm{m}}: 6 \mathrm{~m}$ ). This increase was triggered by the extension of the Rhône River plume, the phytoplankton blooms (highest TChl a values: $1.6 \mu \mathrm{g} \mathrm{L}^{-1}$; Table 1) (48) and the subsequent CDOM increase. Then, $K_{\mathrm{d}}(\lambda)$ diminished during the summer (from July) as a result of decreased primary production (nutrient depletion) (TChl a: $0.2-0.4 \mu \mathrm{g} \mathrm{L}^{-1}$; Table 1) and CDOM photobleaching. In the fall (November), $K_{\mathrm{d}}(\lambda)$ increased as a result of vertical mixing, which led to CDOM and nutrient inputs in the surface waters (Fig. 4).

The $K_{\mathrm{d}}(\mathrm{PAR})$ values measured in this work were similar to those reported for the western Mediterranean basin (73) and were higher than those reported for the eastern basin (74). In contrast, the $K_{\mathrm{d}}(\mathrm{UVR})$ values were lower than those found in the North Aegean Sea (75), the Adriatic Sea (76) and in the coastal waters of Southern Spain (69), but were higher than those determined in the South Aegean Sea (75) and in the Algerian Basin (77). In Rhône River fresh water lenses, higher $K_{\mathrm{d}}(\mathrm{UVR})$ were reported (78). It is important to note that the $K_{\mathrm{d}}(\mathrm{UVR})$ values reported in this study and in the Mediterranean Sea were higher than those reported in the Pacific Ocean at the same TChl $a$ concentrations $(37,42)$.

We examined the linear relationships between $K_{\mathrm{d}}(\lambda)$ and $a_{\mathrm{CDOM}}(350)$ (Fig. 5). The correlation coefficients increased from $K_{\mathrm{d}}(305) \quad\left(R^{2}=0.11, \quad P=0.2\right) \quad$ to $K_{\mathrm{d}}(340) \quad\left(R^{2}=0.76\right.$, $P<0.0001)$ before decreasing to $K_{\mathrm{d}}(565)\left(R^{2}=0.26, P=0.08\right)$ (Fig. 5). While the highest correlations were found at 340 and $380 \mathrm{~nm}$, weak correlations were surprisingly observed at 305 and $325 \mathrm{~nm}$. Our CDOM spectra did not contain any specific "bumps" in the 300-330 nm spectral domain. Also, the correlations were not better when plotting $K_{\mathrm{d}}(305) v s a_{\mathrm{CDOM}}(305)$ and 


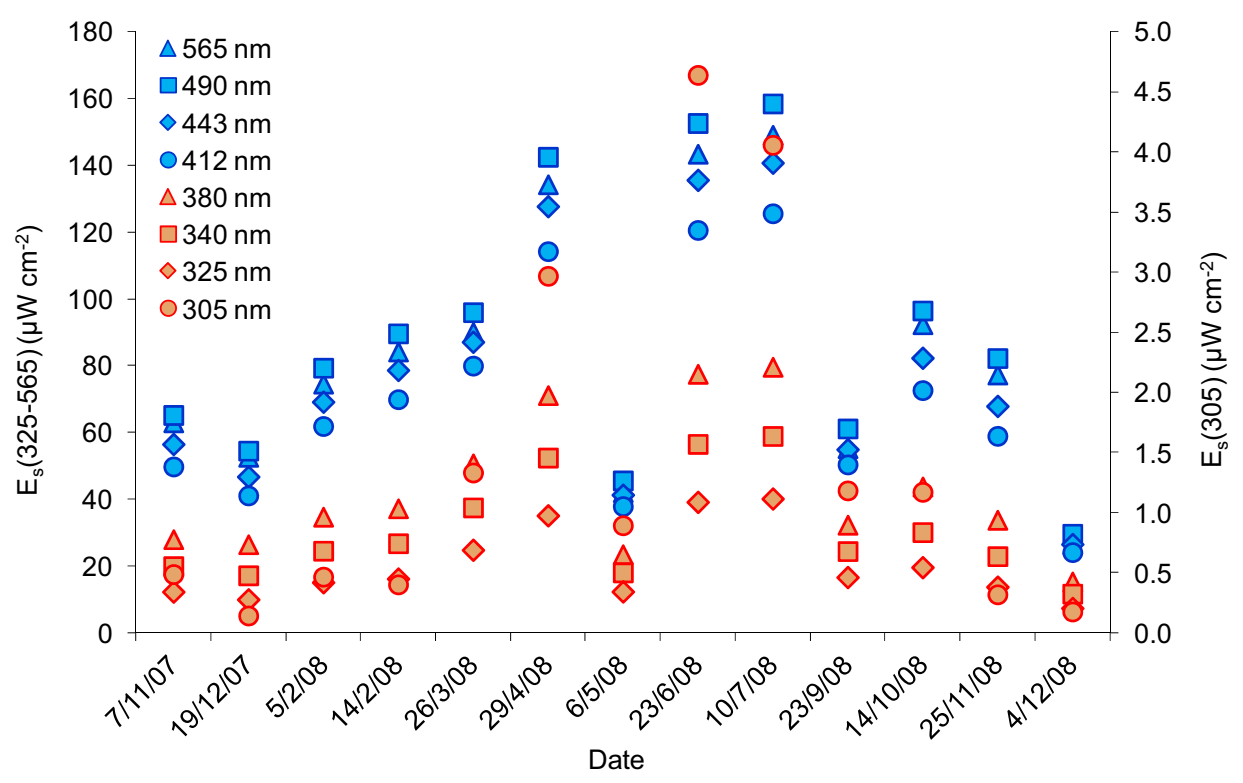

Figure 2. Temporal variability of surface irradiance $\left[E_{\mathrm{s}}(\lambda)\right]$ in the UVR-B $(305 \mathrm{~nm})$, UVR-A $(325,340,380 \mathrm{~nm})$ and PAR $(412,443,490,565 \mathrm{~nm})$ domains measured at solar noon at the SOLEMIO station. $E_{\mathrm{s}}(\lambda)$ at $305 \mathrm{~nm}$ is represented on the secondary axis.

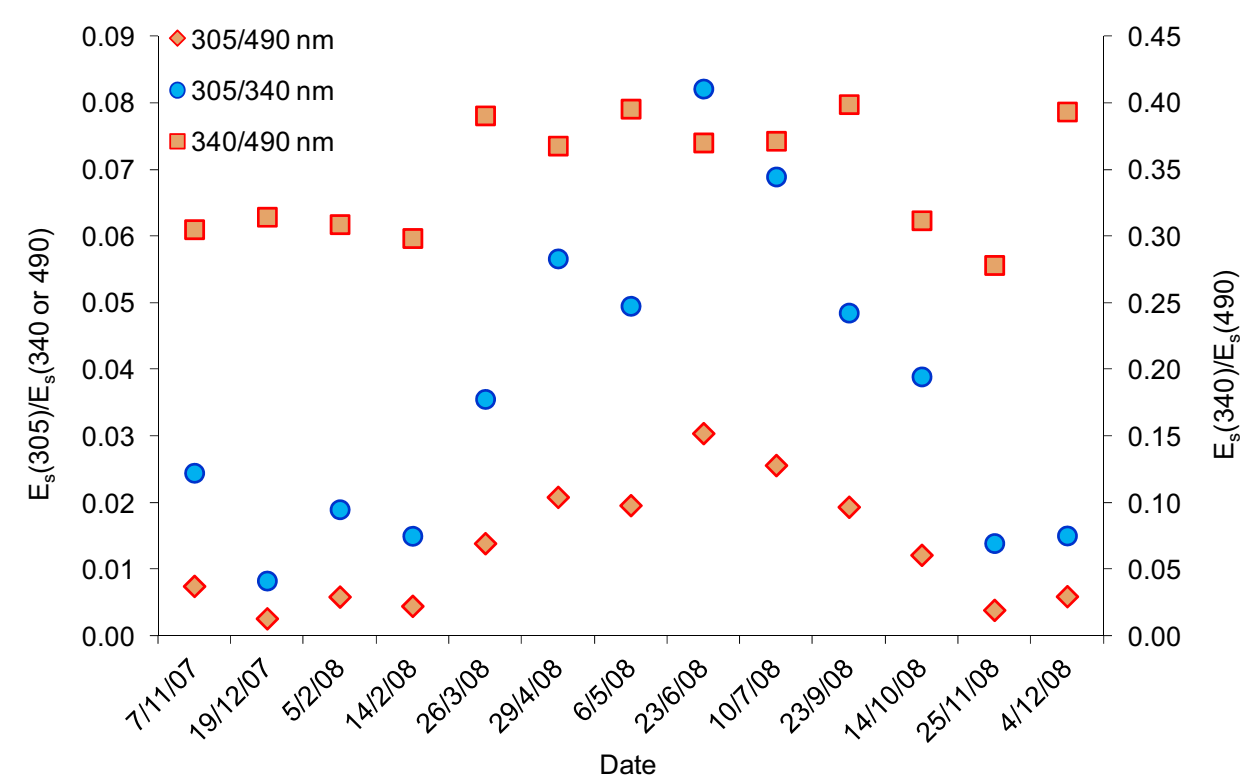

Figure 3. Temporal variability of surface irradiance $\left[E_{\mathrm{s}}(\lambda)\right]$ ratios measured at solar noon at the SOLEMIO station, including UVR-B/UVR-A $(305 / 340 \mathrm{~nm})$, UVR-B/PAR $(305 / 490 \mathrm{~nm})$ and UVR-A/PAR $(340 / 490 \mathrm{~nm})$. The ratio 340/490 $\mathrm{nm}$ is represented on the secondary axis.

$K_{\mathrm{d}}(325)$ vs $a_{\mathrm{CDOM}}(325)$ (Figure not shown). Therefore, the low correlations found between $\mathrm{CDOM}$ and $K_{\mathrm{d}}(\lambda)$ in the shortest UV wavelengths were not issued from specific features in the CDOM spectra, although Organelli et al. (67) observed bumps around $310-320 \mathrm{~nm}$ in CDOM spectra recorded in the Northwestern Mediterranean Sea and attributed them to the presence of dissolved absorbing pigments released by phytoplankton cells, namely mycosporine-like amino acids (MAAs). Our weak correlations could thus result from a contribution of non-algal particulate (NAP). Indeed, NAP, which comprises all the colored particulate material except pigments (i.e. detritus, heterotrophic organisms and minerals), presents the same absorption spectra than CDOM: an exponential increase in absorption coefficients towards the short UV wavelengths (19-22). For this reason, both
CDOM and NAP (defined as the chromophoric detrital matter pool, CDM) contribute to UVR attenuation in marine waters. It is unambiguous that $\mathrm{CDOM}$ is the major contributor accounting for $\sim 80-95 \%$ of CDM in the UV and blue ranges (23-26). Nevertheless, we may make the assumption that in our case (low CDOM content) the absorption of NAP at 305 and $325 \mathrm{~nm}$ could explain the discrepancy between $K_{\mathrm{d}}(\lambda)$ at CDOM absorption at these wavelengths. Besides UVR, CDOM significantly contributed to PAR attenuation at 412 and $443 \mathrm{~nm}$ (Fig. 5). This has been already observed in several works $(23,24)$. Thus, CDOM appeared to be a main contributor to UVR attenuation in the UVA domain (at 340 and $380 \mathrm{~nm}$ ) but not in the UVB domain (at 305 and $325 \mathrm{~nm}$ ), while it also played a significant role in PAR attenuation (at 412 and $443 \mathrm{~nm}$ ). 


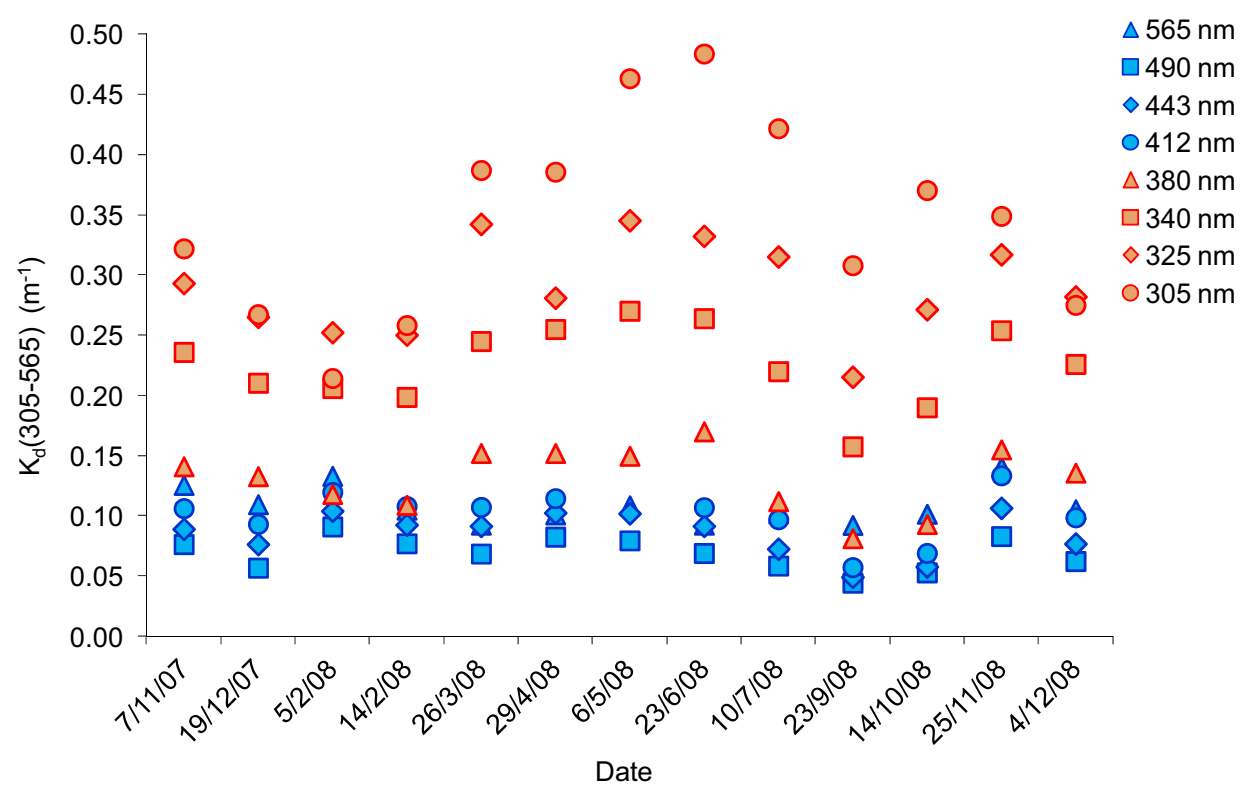

Figure 4. Temporal variability of diffuse attenuation coefficient for downward irradiance $\left[K_{\mathrm{d}}(\lambda)\right]$ in the UVR-B $(305 \mathrm{~nm})$, UVR-A (325, $\left.340,380 \mathrm{~nm}\right)$ and PAR $(412,443,490,565 \mathrm{~nm})$ domains measured at solar noon at the SOLEMIO station.

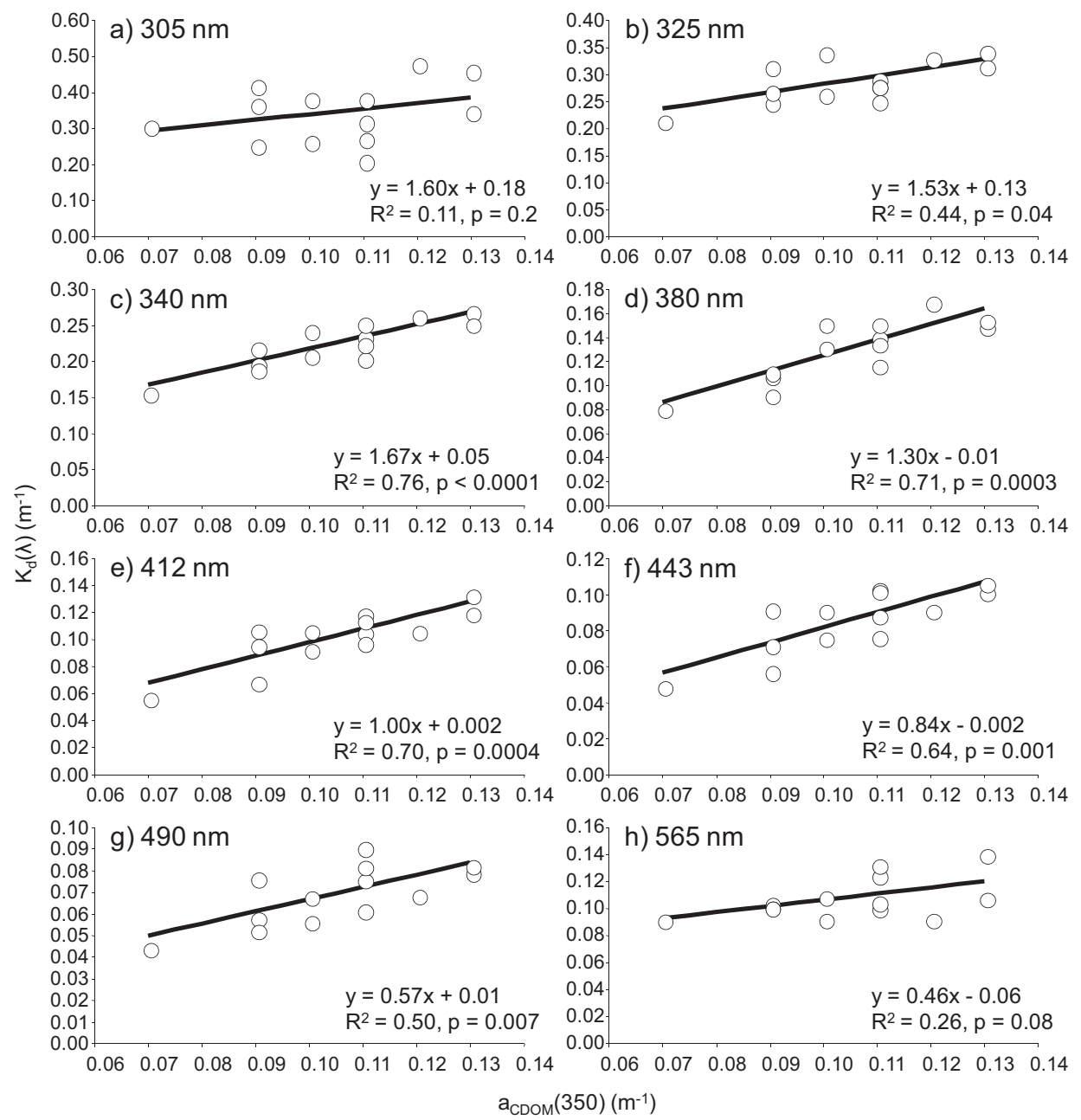

Figure 5. Linear relationships between the CDOM absorption coefficients at $350 \mathrm{~nm}$ [ $\left.a_{\mathrm{CDOM}}(350)\right]$ and the diffuse attenuation coefficients for downward irradiance $\left[K_{\mathrm{d}}(\lambda)\right]$ in the UVR-B $(305 \mathrm{~nm})$, UVR-A $(325,340,380 \mathrm{~nm})$ and PAR $(412,443,490,565 \mathrm{~nm})$ domains. 

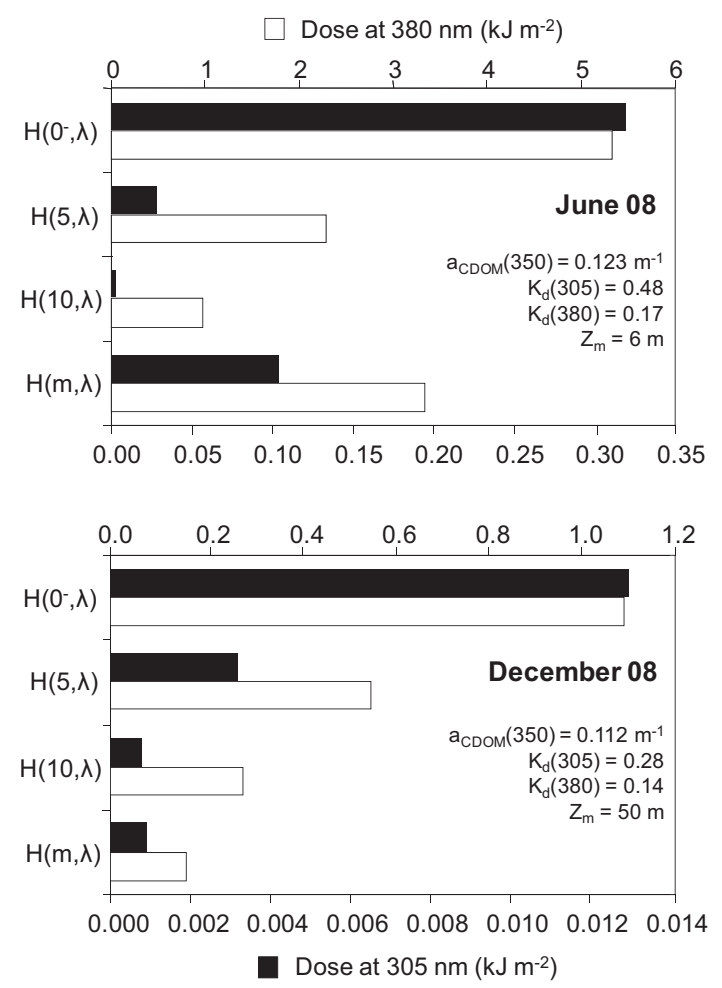

Figure 6. Doses received beneath the sea surface $\left[H\left(0^{-}, \lambda\right)\right]$, doses received at 5 and $10 \mathrm{~m}$ depths into the water column $[H(5, \lambda)$ and $H(10$, $\lambda)]$ and mean doses received within the mixed layer $[H(\mathrm{~m}, \lambda)]$ in the UVR-B $(305 \mathrm{~nm})$ and UVR-A $(380 \mathrm{~nm})$ domains during $2 \mathrm{~h}$ at solar noon at the SOLEMIO station at two different dates: 23 June and 04 December 2008. The wavelength $305 \mathrm{~nm}$ is used as biologically effective wavelength for the induction of DNA damages (CPDs), while $380 \mathrm{~nm}$ is used as biologically effective wavelength for the induction of photorepairs (PERs). Note the different dose scales between June and December.

\section{Underwater UVR doses and influence of the vertical mixing}

Figure 6 shows the doses received beneath the sea surface $[H$ $\left.\left(0^{-}, \lambda\right)\right]$, the doses received at 5 and $10 \mathrm{~m}$ depths $[H(5, \lambda)$ and $H$ $(10, \lambda)]$ and the mean doses received within the mixed layer $[H$ $(\mathrm{m}, \lambda)]$ at 305 and $380 \mathrm{~nm}$ during 2 hours at solar noon at two different dates: 23 June and 04 December 2008. The wavelength 305 and $380 \mathrm{~nm}$ have been chosen as biologically effective wavelengths for the induction of DNA damages (CPDs) and photorepairs (PERs), respectively. These samples (23 June and 04 December) are representative of two contrasted situations. $H$ $\left(0^{-}, 305\right)$ and $H\left(0^{-}, 380\right)$ were much higher in June $(0.32$ and $\left.5.3 \mathrm{~kJ} \mathrm{~m}^{-2}\right)$ than in December $\left(0.013\right.$ and $\left.1.1 \mathrm{~kJ} \mathrm{~m}^{-2}\right)$ as a consequence of much higher levels of surface irradiance in June (sunny day) relative to December (cloudy day) (Table 1; Fig. 2). Obviously, these much higher $\mathrm{H}\left(0^{-}, 305\right)$ and $\mathrm{H}\left(0^{-}, 380\right)$ in June explained the much higher doses received in the water column (5 and $10 \mathrm{~m}$ and mean in the mixed layer depth) compared to December. From $0^{-} \mathrm{m}$, the doses decreased with depth. $H$ $(10,305)$ and $H(10,380)$ were 0.0025 and $0.97 \mathrm{~kJ} \mathrm{~m}^{-2}$ in June and 0.0008 and $0.28 \mathrm{~kJ} \mathrm{~m}^{-2}$ in December (Fig. 6). The June sample was characterized by a higher CDOM content $\left[a_{\mathrm{CDOM}}(350)=0.12 \mathrm{~m}^{-1}\right]$ and a higher UVR attenuation $\left[K_{\mathrm{d}}(305)=0.48 \mathrm{~m}^{-1}, \quad K_{\mathrm{d}}(380)=0.17 \mathrm{~m}^{-1}\right)$ compared to the December one $\left[a_{\mathrm{CDOM}}(350)=0.11 \mathrm{~m}^{-1}, K_{\mathrm{d}}(305)=0.28 \mathrm{~m}^{-1}\right.$, $\left.K_{\mathrm{d}}(380)=0.14 \mathrm{~m}^{-1}\right)$. This explained the fact that the decrease rate of doses from $0^{-}$to $10 \mathrm{~m}$ was more important in June than in December. $H(\mathrm{~m}, 305)$ and $H(\mathrm{~m}, 380)$ were 0.10 and $3.3 \mathrm{~kJ} \mathrm{~m}^{-2}$ in June and 0.0008 and $0.28 \mathrm{~kJ} \mathrm{~m}^{-2}$ in December. $H(\mathrm{~m}, \lambda)$ were thus higher than $H(5, \lambda)$ and $H(10, \lambda)$ in June, while the inverse pattern was observed in December (Fig. 6). This was due to the mixed layer depth $\left(Z_{\mathrm{m}}\right)$ that was low in June $(6 \mathrm{~m})$ and high in December $(50 \mathrm{~m})$. Indeed, an increase in $Z_{\mathrm{m}}$ leads mechanically to a reduction of $\mathrm{H}(\mathrm{m}, \lambda)$ according to Eq. 7 . Hence, we find that the mean UVR doses received in the mixed layer were lower than UVR doses beneath the sea surface by a factor 1.6-18,

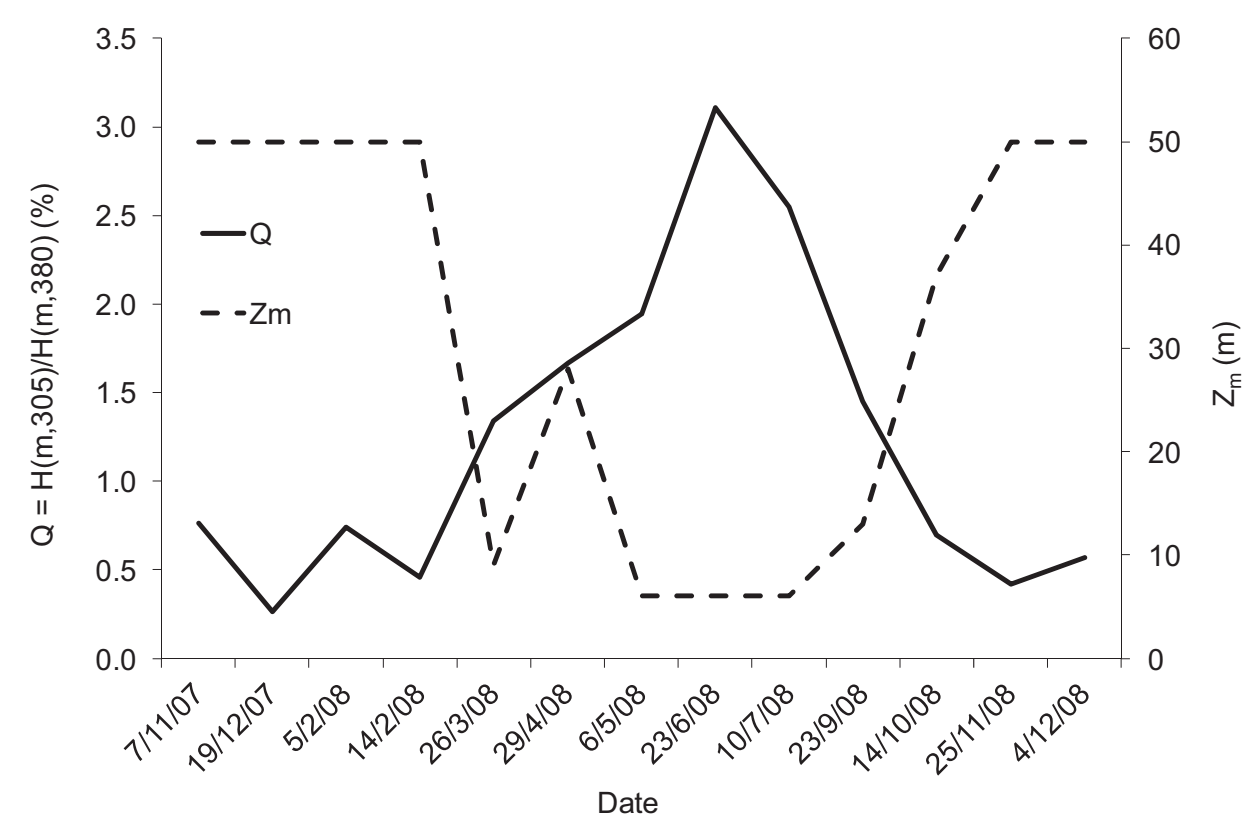

Figure 7. Ratio of the mean doses received within the mixed layer at 305 and $380 \mathrm{~nm}[Q$ in $\%=H(\mathrm{~m}, 305)] / H(\mathrm{~m}, 380) \times 100]$ along with mixed layer depth $\left(Z_{\mathrm{m}}\right.$ in $\left.\mathrm{m}\right)$ at solar noon at the SOLEMIO station. 
which is in line with previous studies $(4,47,48)$. Also, measuring UVR doses at 5 or $10 \mathrm{~m}$ depth induces underestimations (in June) or overestimations (in December) of mean doses received within the mixed layer. These discrepancies underscore the importance of taking into account the vertical mixing to determine the actual UVR doses received by organisms in the surface oceanic waters. Interestingly, the mean doses received within the mixed layer during $2 \mathrm{~h}$ at solar noon in June 2008 in the Bay of Marseilles $\left[H(\mathrm{~m}, 305)\right.$ and $H(\mathrm{~m}, 380)=0.10$ and $3.3 \mathrm{~kJ} \mathrm{~m}^{-2}$ ] were of the same order of magnitude than mean doses received within the mixed layer during the whole day (6:00-18:00) in October 2004 in the vicinity of Marquesas Islands in the South East Pacific $\left(\left[H(\mathrm{~m}, 305)\right.\right.$ and $H(\mathrm{~m}, 380)=0.11$ and $\left.\left.4.2 \mathrm{~kJ} \mathrm{~m}^{-2}\right)\right]$ (47). This was due to the fact that in this latter environment, although surface irradiances were much higher and the UVR attenuation much lower, $Z_{\mathrm{m}}$ was deeper $(89 \mathrm{~m})$ leading, ultimately, to quite equivalent UVR doses in the mixed layer. It is worth noting that a recent work has underlined the impact of the vertical mixing on the inhibitory effect of UVR on primary and bacterial productions in the coastal Mediterranean Sea (79).

The ratio of the mean doses received within the mixed layer at 305 and $380 \mathrm{~nm}[Q$ in $\%=H(\mathrm{~m}, 305)] / H(\mathrm{~m}, 380) \times 100]$ along with the mixed layer depth $\left(Z_{\mathrm{m}}\right)$ are presented in Fig. 7. We use this $Q$ ratio as an indicator of changes in the balance between DNA damages (CPDs) and repairs (PERs), i.e. when $Q$ increases, the importance of CPDs should increase relative to PERs.

Clearly, $Q$ increased with the stratification of the water column (from March to September), and thus the importance of CPDs, to reach a maximal value of 3.0 in June (Fig. 7). The increase in $Z_{\mathrm{m}}$ (enhancement of vertical mixing) caused a drastically reduction of $Q(<1.0)$ in autumn-winter.

\section{CONCLUSION}

This study showed clear temporal variations in the amount of UVR-B that reached the sea surface. The UVR-B intensities were seven- to eight-fold greater in the summer (water stratification period) than in the winter. Fairly low and constant $K_{\mathrm{d}}(\mathrm{UVR})$ and $K_{\mathrm{d}}(\mathrm{PAR})$ values were observed throughout the study period, which illustrated the high transparency of these coastal waters and indicated that UVR is an important physical force that may influence the overall biogeochemistry of this area. CDOM was the dominant factor that controlled UVR attenuation in the UVA domain, but not at shorter UV wavelengths. CDOM also played a significant role in the PAR underwater light field. Undoubtedly, our conclusions are based on a limited number of samples, and additional measurements of CDOM absorption and UVR/PAR attenuation in the Mediterranean Sea are required to confirm these findings. The analyses of the mean doses received within the mixed layer at 305 and $380 \mathrm{~nm}$ (Q in \%) along with the mixed layer depth $\left(Z_{\mathrm{m}}\right)$ indicate the importance of taking into account the vertical mixing to determine the actual UVR doses received by organisms in the surface oceanic waters. Such an approach is very likely necessary for an appropriate estimate of the Mediterranean Sea biogeochemistry in a global warming context.

Acknowledgements-We are very grateful to the SAM department from MIO, the R/V Antédon II and Tethys II crews for their excellent services at sea. We thank associated editor and two anonymous reviewers for improving the quality of the manuscript. This study was conducted as part of the WP4-MERMEX/MISTRALS, UVPACA/SUNMEX, LABEX OT-Med projects funded by INSU-CNRS and Conseil Général des Bouches du Rhône and supported by Pole Mer Méditerranée and Aix Marseille Université. This study is a contribution to the international SOLAS project. We acknowledge the financial support from the PACA region, which provided a PhD scholarship for J. Para.

\section{REFERENCES}

1. Häder, D. P., H. D. Kumar, R. C. Smith and R. C. Worrest (2007) Effects of solar UV radiation on aquatic ecosystems and interactions with climate change. Photochem. Photobiol. Sci. 6, 267-285.

2. Antoine, D., M. Babin, J. F. Berthon, A. Bricaud, B. Gentili, H. Loisel, S. Maritorena and D. Stramski (2014) Shedding light on the sea: André Morel's legacy to optical oceanography. Ann. Rev. Mar. Sci. 6, 1-21.

3. Mostajir, B., S. Demers, S. J. Mora, R. P. Bukata and J. H. Jerome (2000) Implications of UV radiation for the food web structure and consequences on the carbon flow. In The Effects of UV Radiation in the Marine Environment (Edited by S. de Mora, S. Demers and M. Vernet), pp. 310-320. Cambridge University Press, New York.

4. Jeffrey, W. H., P. Aas, M. M. Lyons, R. B. Coffin, R. Pledger and D. L. Mitchell (1996) Ambient solar radiation induced photodamage in marine bacterioplankton. Photochem. Photobiol. 64, 419-427.

5. Vincent, W. F. and P. J. Neale (2000) Mechanisms of UV damage to aquatic organisms. In The Effects of UV Radiation in the Marine Environment (Edited by de Mora S., S. Demers and M. Vernet), pp. 149-176. Cambridge University Press, New York.

6. Villafane, V. E., P. J. Janknegt, M. de Graaff, J. W. Visser, W. H. van de Poll, A. G. J. Buma and E. W. Helbling (2008) UVR-induced photoinhibition of summer marine phytoplankton communities from Patagonia. Mar. Biol. 154, 1021-1029.

7. Ruiz-González, C., T. Lefort, M. Galí, M. Montserrat Sala, R. Sommaruga, R. Simó and J. M. Gasol (2012) Seasonal patterns in the sunlight sensitivity of bacterioplankton from Mediterranean surface coastal waters. FEMS Microbiol. Ecol. 79, 661-674.

8. Häder, D. P. and R. P. Sinha (2005) Solar ultraviolet radiationinduced DNA damage in aquatic organisms: potential environmental impact. Mutat. Res. 571, 221-223.

9. Joux, F., W. H. Jeffrey, P. Lebaron and D. L. Mitchell (1999) Marine bacterial isolates display diverse responses to UV-B radiation. Appl. Environ. Microbiol. 65, 3820-3827.

10. Friedberg, E. C. (2003) DNA damage and repair. Nature 421, 436-440.

11. Rastogi, R. P., S. P. Singh, D. P. Häder and R. P. Sinha (2011) Ultraviolet-B-induced DNA damage and photorepair in the cyanobacterium Anabaena variabilis PCC 7937. Environ. Exp. Bot. 74, 280-288.

12. Mopper, K. and D. J. Kieber (2002) Photochemistry and the cycling of carbon, sulphur, nitrogen and phosphorus. In Biogeochemistry of Marine Dissolved Organic Matter (Edited by D. A. Hansell and C. A. Carlson), pp. 455-507. Academic Press, San Diego, CA.

13. Boelen, P., M. J. Veldhuis and A. G. Buma (2001) Accumulation and removal of UVBR-induced DNA damage in marine tropical plankton subjected to mixed and simulated non-mixed conditions. Aquat. Microb. Ecol. 24, 265-274.

14. Morel, A., H. Claustre, D. Antoine and B. Gentili (2007a) Natural variability of bio-optical properties in case 1 waters: attenuation and reflectance within the visible and near-UV spectral domains, as observed in South Pacific and Mediterranean waters. Biogeosciences 4, 913-925.

15. Kirk, J. T. O. (1994) Light and Photosynthesis in Aquatic Ecosystems, 2nd edn. Cambridge University Press, Cambridge.

16. Lutz, V. A., S. Sathyendranath and E. J. H. Head (1996) Absorption coefficient of phytoplankton: Regional variations in the North Atlantic. Mar. Ecol. Prog. Ser. 135, 197-213.

17. Dupouy, C., H. Loisel, J. Neveux, S. L. Brown, C. Moulin, J. Blanchot, A. Le Bouteiller and M. R. Landry (2003) Microbial absorption and backscattering coefficients from in situ and POLDER satellite data during an El Nino-Southern Oscillation cold phase in the equatorial Pacific $\left(180^{\circ}\right)$. J. Geophys. Res., 108(C12), 8138.

18. Bricaud, A., H. Claustre, J. Ras and K. Oubelkheir (2004) Natural variability of phytoplanktonic absorption in oceanic waters: Influence 
of the size structure of algal populations. J. Geophys. Res. 109, C11010.

19. Bricaud, A., A. Morel and L. Prieur (1981) Absorption by dissolved organic matter of the sea (yellow substance) in the UV and visible domains. Limnol. Oceanogr. 26, 43-53.

20. Nelson, N. B., D. A. Siegel and A. R. Michaels (1998) Temporal dynamics of colored dissolved material in the Sargasso Sea. DeepSea Res. 145, 931-957.

21. Swan, C. M., D. A. Siegel, N. B. Nelson, C. A. Carlson and E. Nasir (2009) Biogeochemical and hydrographic controls on chromophoric dissolved organic matter distribution in the Pacific Ocean. Deep-Sea Res. I Oceanogr. Res. Pap. 56, 2175-2192.

22. Tilstone, G. H., S. W. M. Peters, H. J. van derWoerd, M. A. Eleveld, K. Ruddick, W. Schönfeld, H. Krasemann, V. Martinez-Vicente, D. Blondeau-Patissier, R. Röttgers, K. Sørensen, P. V. Jørgenseng and J. D. Shutler (2012) Variability in specific-absorption properties and their use in a semi analytical ocean colour algorithm for MERIS in north sea and western English channel coastal waters. Remote Sens. Environ. 118, 320-338.

23. Siegel, D. A., S. Maritorena, N. B. Nelson, D. A. Hansell and M. Lorenzi-Kayser (2002) Global distribution and dynamics of colored dissolved and detrital organic materials. J. Geophys. Res. 107(C12), 3228

24. Siegel, D. A., S. Maritorena, N. B. Nelson and M. J. Behrenfeld (2005) Independence and interdependencies of global ocean color properties: Reassessing the bio-optical assumption. J. Geophys. Res. 110, C07011.

25. Tedetti, M., B. Charrière, A. Bricaud, J. Para, P. Raimbault and R. Sempéré (2010) Distribution of normalized waterleaving radiances at UV and visible wave bands in relation with chlorophyll a and colored detrital matter content in the southeast Pacific. J. Geophys. Res. 115, C02010.

26. Nelson, N. B. and D. A. Siegel (2013) The Global Distribution and Dynamics of Chromophoric Dissolved Organic Matter. Annu. Rev. Mar. Sci. 5, 447-476.

27. Vasilkov, A., N. Krotkov, J. Herman, C. Mc Clain, K. Arrigo and W. Robinson (2001) Global mapping of underwater UV irradiances and DNA-weighted exposures using Total Ozone Mapping Spectrometer and Sea-viewing Wide Field-of-view Sensor data products. J. Geophys. Res. 106, 27205-27219.

28. Seckmeyer, G., D. Pissulla, M. Glandorf, D. Henriques, B. Johnsen, A. Webb, M. Siani, A. Bais, B. Kjeldstad, C. Brogniez, J. Lenoble, B. Gardiner, P. Kirsch, T. Koskela, J. Kaurola, B. Uhlmann, H. Slaper, P. den Outer, M. Janouch, P. Werle, J. Gröbner, B. Mayer, A. de la Casiniere, S. Simic and F. Carvalho (2008) Variability of UV irradiance in Europe. Photochem. Photobiol. 84, 172-179.

29. Mermex Group (2011) Marine ecosystems' responses to climatic and anthropogenic forcings in the Mediterranean. Progr. Oceanogr. 91, 593-594.

30. Vantrepotte, V. and F. Melin (2010) Temporal variability in Seawifs derived apparent optical properties in European seas. Cont. Shelf Res. 30, 319-334.

31. Claustre, H. and S. Maritorena (2003) The many shades of ocean blue. Science 302, 1514-1515.

32. Lee, Z. P. and C. Hu (2006) Global distribution of case-1 waters: An analysis from SeaWiFS measurements. Remote Sens. Environ. 101, 270-276.

33. Morel, A. and B. Gentili (2009) The dissolved yellow substance and the shades of blue in the Mediterranean Sea. Biogeosciences 6, 2625-2636.

34. Loisel, H., V. Vantrepotte, K. Norkvist, X. Mériaux, M. Kheireddine, J. Ras, M. Pujo-Pay, Y. Combet, K. Leblanc, G. Dall'Olmo, R. Mauriac, D. Dessailly and T. Moutin (2011) Characterization of the bio-optical anomaly and diurnal variability of articulate matter, as seen from scattering and backscattering coefficients, in ultra-oligotrophic eddies of the Mediterranean Sea. Biogeosciences 8, 3295-3317.

35. Stambler, N. (2012) Underwater light field of the Mediterranean Sea. In Life in the Mediterranean Sea: A Look at Habitat Changes (Edited by N. Stambler), pp. 175-199. Nova Science Publishers, New York.

36. Claustre, H., A. Morel, S. B. Hooker, M. Babin, D. Antoine, K. Oubelkheir, A. Bricaud, K. Leblanc, B. Queguiner and S. Maritorena (2002) Is desert dust making oligotrophic waters greener? Geophys. Res. Lett. 29, 1469.
37. Morel, A., B. Gentili, H. Claustre, M. Babin, A. Bricaud, J. Ras and F. Tieche (2007b) Optical properties of the "clearest" natural waters. Limnol. Oceanogr. 52, 217-229.

38. Sempéré, R., B. Charrière, G. Cauwet and F. Van-Wambeke (2000) Carbon inputs of the Rhône River to the Mediterranean Sea: Biogeochemical implications. Global Biogeochem. Cycles 14, 669-681.

39. Antoine, D., F. D’Ortenzio, S. B. Hooker, G. Bécu, B. Gentili, D. Taillez and A. J. Scott (2008) Assessment of uncertainty in the ocean reflectance determined by three satellite ocean color sensors (MERIS, SeaWiFS and MODIS-A) at an offshore site in the Mediterranean Sea (BOUSSOLE project). J. Geophys. Res. 113, C07013.

40. Dubovik, O. and M. D. King (2000) A flexible inversion algorithm for retrieval of aerosol optical properties from Sun and sky radiance measurements. J. Geophys. Res. 105, 20673-20696.

41. Holben, B. N., T. F. Eck, I. Slutsker, D. Tanré, J. P. Buis, A. Setzer, E. Vermote, J. A. Reagan, Y. J. Kaufman, T. Nakajima, F. Lavenu, I. Jankowiak and A. Smirnov (1998) AERONET - a Federated Instrument Network and Data Archive for aerosol characterization. Remote Sens. Environ. 66, 1-16.

42. Tedetti, M., R. Sempéré, A. Vasilkov, B. Charrière, D. Nérini, W. L. Miller, K. Kawamura and P. Raimbault (2007) High penetration of ultraviolet radiation in the south east Pacific waters. Geophys. Res. Lett. 34, L12610.

43. Para, J., B. Charrière, A. Matsuoka, W. L. Miller, J. F. R. Rontan and R. Sempéré (2013) UV/PAR radiations and DOM properties in surface coastal waters of the Canadian shelf of the Beaufort Sea during summer 2009. Biogeosciences 10, 2761-2774.

44. Zaneveld, R. J. V., E. Boss and A. Barnard (2001) Influence of surface waves on measured and modeled irradiance profiles. Appl. Opt. 40, 1442-1449.

45. Smith, R. and C. Baker (1984) Analysis of ocean optical data. In Ocean Optics VII, Vol. 478 (Edited by M. Blizard), pp. 119-126. SPIE.

46. Jin, Z., T. P. Charlock, W. L. Jr Smith and K. Rutledge (2004) A parameterization of ocean surface albedo. Geophys. Res. Lett. 31, L22301.

47. Van Wambeke, F., M. Tedetti, S. Duhamel and R. Sempéré (2009) Diel variability of heterotrophic bacterial production and underwater UV doses in the eastern South Pacific. Mar. Ecol. Progr. Ser. 387, 97-108.

48. Boelen, P., M. K. de Boer, G. W. Kraay, M. J. Veldhuis and A. G. Buma (2000) UVBR-induced DNA damage in natural marine picoplankton assemblages in the tropical Atlantic Ocean. Mar. Ecol. Prog. Ser. 193, 1-9.

49. Williamson, C. E., P. J. Neale, G. Grad, H. J. De Lange and B. R. Hargreaves (2001) Beneficial and detrimental effects of UV on aquatic organisms: implications of spectral variation. Ecol. Appl. 11, 1843-1857.

50. D’Sa, E. J., R. G. Steward, A. Vodacek, N. V. Blough and D. Phinney (1999) Determining optical absorption of colored dissolved organic matter in seawater with a liquid capillary waveguide. Limnol. Oceanogr. 44, 1142-1148.

51. Helms, J. R., A. Stubbins, J. D. Ritchie, E. C. Minor, D. J. Kieber and K. Mopper (2008) Absorption spectral slopes and slope ratios as indicators of molecular weight, source, and photobleaching of chromophoric dissolved organic matter. Limnol. Oceanogr. 53, 955-969.

52. Sohrin, R. and R. Sempéré (2005) Temporal variation in total organic carbon in the Northeast Atlantic in 2000-2001. J. Geophys. Res. 110, C10S90.

53. Para, J., P. G. Coble, B. Charrière, M. Tedetti, C. Fontana and R. Sempéré (2010) Fluorescence and absorption properties of chromophoric dissolved organic matter (CDOM) in coastal surface waters of the northwestern Mediterranean Sea, influence of the Rhone River. Biogeosciences 7, 4083-4103.

54. Pairaud, I. L., J. Gatti, N. Bensoussan, R. Verney and P. Garreau (2011) Hydrology and circulation in a coastal area off Marseille: Validation of a nested 3D model with observations. J. Mar. Syst. 88, 20-33.

55. Fraysse, M., I. Pairaud, O. N. Ross, V. M. Faure and C. Pinazo (2014) Intrusion of Rhone River diluted water into the Bay of Marseille: Generation processes and impacts on ecosystem functioning. J. Geophys. Res. 119, 6535-6556.

56. Blough, N. V. and R. Del Vecchio (2002) Chromophoric DOM in the coastal environment. In Biogeochemistry of Marine Dissolved 
Organic Matter (Edited by D. A. Hansel and C. A. Carlson), pp. 509-546. Academic Press, San Diego, California.

57. Kowalczuk, P., W. J. Cooper, M. J. Durako, A. E. Kahn, M. Gonsior and H. Young (2010) Characterization of dissolved organic matter fluorescence in the South Atlantic Bight with use of PARAFAC model: Relationships between fluorescence and its components, absorption coefficients and organic carbon concentrations. Mar. Chem. 118, 22-36.

58. Fichot, C. G. and R. Benner (2011) A novel method to estimate DOC concentrations from CDOM absorption coefficients in coastal waters. Geophys. Res. Lett. 38, L03610.

59. Mannino, A., M. Novak, S. Hooker, K. Hyde and D. Aurin (2014) Algorithm development and validation of CDOM properties for estuarine and continental shelf waters along the northeastern U.S. coast. Remote Sens. Environ. 152, 576-602.

60. Nelson, N. B. and D. A. Siegel (2002) Chromophoric DOM in the open ocean. In Biogeochemistry of Marine Dissolved Organic Matter (Edited by D. A. Hansel and C. A. Carlson), pp. 547-578. Academic Press, San Diego, California.

61. Andrew, A. A., R. Del Vecchio, A. Subramaniam and N. V. Blough (2013) Chromophoric dissolved organic matter (CDOM) in the Equatorial Atlantic Ocean: Optical properties and their relation to CDOM structure and source. Mar. Chem. 148, 33-43.

62. Kitidis, V., A. P. Stubbins, G. Uher, R. C. Upsill Goddard, C. S. Law and E. M. S. Woodward (2006) Variability of chromophoric organic matter in surface waters of the Atlantic Ocean. Deep-Sea Res. II 53, 1666-1684.

63. Coble, P. G. (2007) Marine Optical Biogeochemistry - the chemistry of ocean color. Chem. Rev. 107, 402-418.

64. Bricaud, A., M. Babin, H. Claustre, J. Ras and F. Tièche (2010) Light absorption properties and absorption budget of Southeast Pacific waters. J. Geophys. Res. 115, C08009.

65. Swan, C. M., N. B. Nelson and D. A. Siegel (2013) A model for remote estimation of ultraviolet absorption by chromophoric dissolved organic matter based on the global distribution of spectral slope. Remote Sens. Environ. 136, 277-285.

66. Vantrepotte, V., F. P. Danhiez, H. Loisel, S. Ouillon, X. Mériaux, A. Cauvin and D. Dessailly (2015) CDOM-DOC relationship in contrasted coastal waters: implication for DOC retrieval from ocean color remote sensing observation. Opt. Express 23, 33-54.

67. Organelli, E., A. Bricaud, D. Antoine and A. Matsuoka (2014) Seasonal dynamics of light absorption by chromophoric dissolved organic matter (CDOM) in the NW Mediterranean Sea (BOUSSOLE site). Deep Sea Res. I 91, 72-85.

68. Pavlov, A. K., A. Silyakova, M. A. Granskog, R. G. J. Bellerby, A. Engel, K. G. Schulz and C. P. D. Brussaard (2014) Marine CDOM accumulation during a coastal Arctic mesocosm experiment: No response to elevated pCO2 levels. J. Geophys. Res. Biogeosci. 119, $1216-1230$.

69. Figueroa, F. L., C. Jiménez, B. Viñegla, E. Pérez-Rodríguez, J. Aguilera, A. Flores-Moya, M. Altamirano, M. Lebert and D. P. Häder (2002) Effects of solar UV radiation on photosynthesis of the marine angiosperm Posidonia oceanica from southern Spain. Mar. Ecol. Progr. Ser. 230, 59-70.

70. Vasseur, C., B. Mostajir, C. Nozais, M. Denis, E. Fouilland, B. Klein and S. Demers (2003) Effects of bio-optical factors on the attenuation of ultraviolet and photosynthetically available radiation in the North Water Polynya, northern Baffin Bay: Ecological implications. Mar. Ecol. Progr. Ser. 252, 1-13.

71. Kuwahara, V. S., R. Nakajima, B. H. R. Othman, M. R. M. Kushairi and T. Toda (2010) Spatial variability of UVR attenuation and bio-optical factors in shallow coral-reef waters of Malaysia. Coral Reefs 29, 693-704.

72. Tedetti, M. (2006) Impact du rayonnement ultraviolet sur la phototransformation de la matière organique dissoute en milieu marin. $\mathrm{PhD}$ thesis, Université de la Méditerranée, Marseille, France.

73. Morán, X. A. G. and M. Estrada (2001) Short-term variability of photosynthetic parameters and particulate and dissolved primary production in the Alboran Sea (SW Mediterranean). Mar. Ecol. Progr. Ser. 212, 53-67.

74. Moutin, T. and P. Raimbault (2002) Primary production, carbon export and nutrients availability in western and eastern Mediterranean Sea in early summer 1996. J. Mar. Syst. 33-34, 273-288.

75. Obernosterer, I., G. Kraay, E. de Ranitz and G. J. Herndl (1999) Concentrations of low molecular weight carboxylic acids and carbonyl compounds in the Aegean Sea (Eastern Mediterranean) and the turn-over of pyruvate. Aqua. Microb. Ecol. 20, 147-156.

76. Sommaruga, R., I. Obemosterer, G. J. Herndl and R. Psenner (1997) Inhibitory effect of solar radiation on thymidine and leucine incorporation by freshwater and marine bacterioplankton. Appl. Environ. Microb. 63, 4178-4184.

77. Llabrés, M., S. Agustí, P. Alonso-Laita and G. J. Herndl (2010) Synechococcus and Prochlorococcus cell death induced by UV radiation and the penetration of lethal UVR in the Mediterranean Sea. Mar. Ecol. Progr. Ser. 399, 27-37.

78. Joux, F., W. H. Jeffrey, M. Abboudi, J. Neveux, M. Pujo-Pay, L. Oriol and J. J. Naudin (2009) Ultraviolet radiation in the Rhône River lenses of low-salinity and in marine waters of the Northwestern Mediterranean Sea: Attenuation and effects on bacterial activities and net community production. Photochem. Photobiol. 85, 783-793.

79. Bertoni, R., W. H. Jeffrey, M. Pujo-Pay, L. Oriol, P. Conan and F. Joux (2011) Influence of water mixing on the inhibitory effect of UV radiation on primary and bacterial production in Mediterranean coastal water. Aquat. Sci. 73, 377-387. 